\title{
Shaping Place Identity in Urban Village through R-V-S-T Participatory Art model
}

\author{
Ernest Irwandi Setiawan Sabana Andryanto Rikrik Kusmara Tisna Sanjaya \\ Faculty of Arts and Design, Institut Teknologi Bandung Ganesha 10, Bandung 40132, Indonesia
}

\begin{abstract}
For over a decade, urban villages across Java Indonesia that were used to be slum areas were transformed into colorful villages and have become tourist destinations. Artists together with local residents paint the village with colorful murals, thus the name Kampung Pelangi or Rainbow Village become synonymous with the creative movement. This study was conducted in Kampung Pelangi of Semarang city, in central Java Indonesia. Kampung Pelangi of Semarang City is visually unique it is located on a hill slope and the expansive paintings of the village created colorful terraced settlement. However, to ensure its sustainability as a tourist destination and a good dwelling place, residents' creativity is the key factor to perform continual improvements. Kampung Pelangi in Semarang City is surrounded by historical sites, which intersects with the city's geographical history. Hence rediscovering its historical narrative is an important effort to strengthened its place identity. This study explores how art and design are incorporated in participatory action model to shape place identity in the urban village. The participatory art modeled based on study of traditional heritage, existing vernacular creativity, place history and territorial narration. The culmination of these factors regarded as collective identity expression and modeled as Relational, Vernacular, Symbolical, Territorial (R-V-S-T) expressions for participatory art practices. This study uses qualitative approach. The participatory art model is developed based on research data gathered from in depth interviews, focus group discussions, participant observations, literature study on participatory models. The practical aim of this study is to model a new form of tourism by enriching local values which can lead towards place sustainability. As contribution to art and design research literature, this study proposed R-V-S-T as a model for meaning creation in collaborative artistic process specifically in shaping place identity in urban villages.
\end{abstract}

Keywords: Participatory Art Model, Urban Villages, Place Identity

DOI: $10.7176 / \mathrm{ADS} / 95-04$

Publication date:September $30^{\text {th }} 2021$

\section{Introduction}

Over the past decade there is an emergence of colorful urban villages across cities of Java Indonesia, popularly known as 'Kampung Pelangi' or rainbow village. Several urban villages have become the icon of the city and become tourist destinations due to its uniqueness. The common practice performed in these urban village projects is by painting the houses, creating colorful attractive sites, thus Kampung Pelangi or rainbow village became a new social and artistic movement across urban areas of Java, Indonesia. These rainbow villages attract many visitors and gradually transform the villages into tourist destinations and triggering local economy. Success story of one rainbow village project appropriated by other urban villages which eventually increasing further participation of many stakeholders in various collaborative empowerment projects.

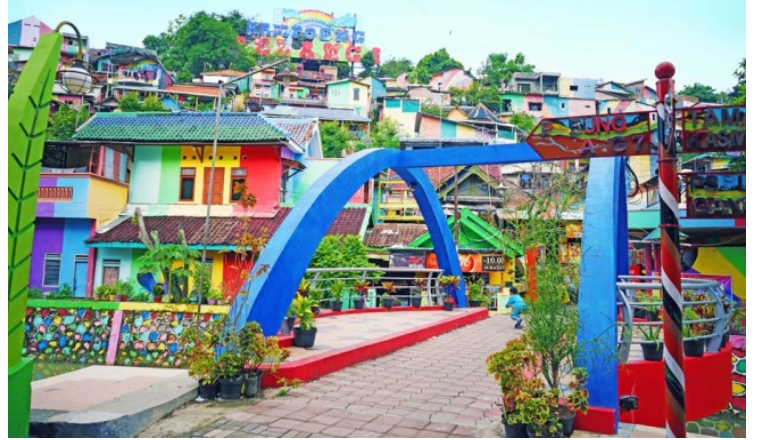

Figure 1. Kampung Pelangi entrance photographed in 2019

Kampung Pelangi located in Semarang city Central Java, was previously known as Wonosari. It is approximately 4 hectares consist of approximately 300 houses. Between 1970s to 1980s very few inhabitants lived in the area and most of this area is empty, most of the area is used for public cemetery known as Bergota. After the 1998 Indonesia economic crisis, the number of inhabitants had increased drastically due to affordable land price (Sunarjan, 2014). The area was never designated as housing district by the government therefore building construction were not well managed and have very minimal basic facilities such as clean water, waste 
management and security. By late 1990s and early 2000, the area is known as slum area. In 2017 Wonosari undergo major revitalization for tourism, initiated by Semarang City government and supported by corporate responsibility programs conducted by corporations in central java. The revitalization project resulted painting 300 houses and building small bridges. Wonosari name was changed to Kampung Pelangi and it became the new icon of Semarang city. In 2017 Kampung Pelangi Semarang is opened to the public and attracts national and international tourists.

The coloring of the village had transformed the village physically, however to ensure Kampung Pelangi's sustainability as tourist destination and as a good dwelling place, there are sectors needed for improvements. The location of Kampung Pelangi is surrounded by historic sites and there are local communities still conserving traditional values which are good indications for strong place narratives. To increase its potentials, these unique historic and cultural values should be further explored and strengthened. Hence, there is urgency for a collaborative model which combines of creative practices and social empowerment towards place sustainability and shape place identity.

\section{Method}

This study used a qualitative approach to examine the participatory art model to shape place identity in urban villages. Data analysis for this study is gathered from in depth interview, field and participant observations and supported by participatory action research literatures. The study is conducted in Kampung Pelangi in Semarang City, Central Java Indonesia. Series of interviews were conducted with leaders and residents of Kampung Pelangi between 2019-2021. Participant observation also conducted in the Participatory art projects implemented in 2021, where researcher involved in collaborative project with Art Communities, residents of Kampung Pelangi, and Semarang Youth Organizations, in which a participatory art project was exercised in 2021.

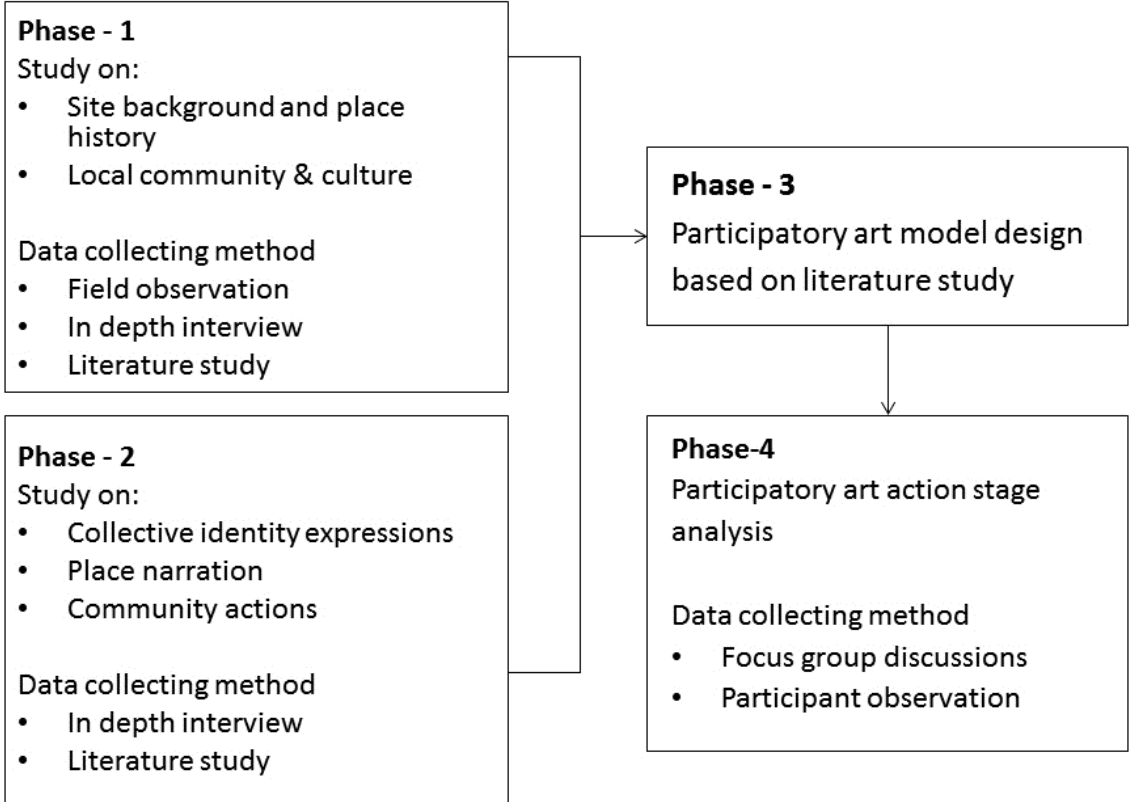

Figure 2. Research phase and data collecting methods

Data validation of 2021 participatory action, conducted through focus group discussions with residents of Kampung Pelangi, government officials, historians, university students and educators.

\section{Results and Discussions}

The study findings in Kampung Pelangi highlights two aspects; first is re-discovering and reviving the geographical history of the village which has deep intersections with the history of Semarang city. Second aspect highlights various activities performed by 5 existing and important local communities in building social relations and community cohesion in Kampung Pelangi. The 5 local communities are:

- PAKAS, - Semarang River Community, which was formed in 2017 at RW 04 Randusari, conducted various activities to improve river conditions such as cleaning the river and held fishing competition to raise awareness and raising funds for the conservation of Semarang River.

- The GETAWILANG music community, foster younger generation in Kampung pelangi to learn and practice 'Gamelan' a traditional Javanese musical instrument.

- The Jathilan dance community, foster younger generation to learn and practice traditional Javanese dance. 
- Karang Taruna a youth organization that organizes various activities in Kampung Pelangi such as sport activities, cleaning the village and help other community activites.

- $\quad$ PKK or family welfare and education community, organize activities in educating women in Kampung Pelangi. The activities varies from cooking activity and developing local cullinary, crafting usable products from recycled materials and collaborate with local government to inform residents about health and family welfare programs.

\subsection{Place Identity Expressions}

The geographical history of the village and the efforts made by the residents are the main focus in shaping place identity. The interrelation between place identity, place narration and the residents collective espression, were identified and classified into 4 conceptual category: relational, vernacular, symbolic, and territorial expressions.

\subsubsection{Relational expressions}

Relational expressions category is based on Bourriaud's (2002) concept of relational aesthetics. Bourriaud's concept of relational aesthetics explains that works of art can produce models of sociability. Relational artworks can be a source of inspiration for audiences, presenting an exchange of experiences and strengthening relational space in social life. The colorful murals of Kampung Pelangi have established new form of relations between residents, tourists and urbanites. To the residents the colorful village become a new platform which opened new opportunity to enhance local economy. It become a dependable creative space to explore various creativity. To the urbanites and the tourist it is to experience local culture and creativity and relation to a new place.

\subsubsection{Vernacular creativity expressions}

According to Heath (2009), vernacular creativity involves practices of representation, expression, knowledge, and skills that originate from cultural heritage and are understood regionally (p.8). Over time, vernacular creativity can be transitional or change collectively because cultural heritage is always renewed by communities in response to the changing environment. Interaction with the natural environment creates distinctive customs that differ from mainstream culture. The vernacular creativity represents the unique characteristics of Kampung Pelangi, which differentiate it from other places. There were several creative community found in Kampung Pelangi. Residents practicing and developing skills in traditional art community such as in Getawilang Gamelan community, a traditional Javanese music performances and Jathilan traditional Javanese dance. There was also a community that produced authentic local culinary such as Wedhang Asem Jawa a traditional hot tamarind beverage. The Wedhang Asem beverage can be found across Java island however tamarind plant has a special connection to the history of Semarang city. The name of Semarang city was given by Ki Ageng Pandanaran, the first regent of the region. The word Semarang originates from the Javanese word 'asem arang-arang' or tamarind plants that were planted spaced apart.

\subsubsection{Symbolic expressions}

The term symbolic expression in this study refers to Paasi's (1986) concept of symbolic shape. According to Paasi (1986), the symbolic shape or territorial symbols are abstract expressions of group solidarity, embodying continual process of actions in the reproduction and legitimation of practices and institution that characterize or shaped the regional identity (p.126). The regional identity refers to the distinctive natural and cultural qualities of a region (Paasi,2003). According to Raagmaa (2002), the interpretation of activities in public spaces and various forms of heritage always develops and changes over time. Changes indicate a process of 're-symbolization' that is continuously negotiated and actively produced by the local community, which can be examined when citizens reuse and reinterpret historical and traditional symbols in the present context. Symbols of a region can be symbols of the nature or material in shape such as buildings. Since Kampung Pelangi is located in Bergota cemetery area, many houses in the village is surrounded by old graves and several of them are graves of Semarang's important figures. There are stories about the historical figures that are known among elderly residents. Those stories narrate about loyalty, honesty, compassion, justice and bravery. Those stories are continually told to younger generations. The good character traits of the historical figure have become exemplary model to younger generation and symbols for good behavior and attitude to follow.

\subsubsection{Territorial expressions}

According to Raagmaa (2001), the formation of a region is a territorial process that occurs when there is competing interest in the function and meaning of a place, and efforts to redefine or rethink the function of a place is a 're-territorialization' efforts.

Transformation of Kampung Pelangi into tourist destination is a 're-territorialization' effort initiated by the city government. Kampung Pelangi is previously known as Wonosari, a dense dwelling place in Semarang City. During late 1990s and early 2000, the area is known as slum area. Due to its strategic locations, it undergo 
revitalization in 2017 and the area beccame part of the thematic village program initiated by Semarang City government. Kampung Pelangi is located on Brintik Hill within the Bergota cemetery area, one of the oldest cemetery in Central Java. Its locations is also surrounded by historical sites and buildings such as Lawang Sewu, a locomotive company building built in 1919 during Dutch colonial era which still stands to this day and it is just 800 meters from Kampung Pelangi. Second historic building is Cathedral of St. Virgin Mary Queen of the Rosary built in 1927, located 500 meters from Kampung Pelangi. Third historic building is Mandala Bhakti Museum a military museum located 550 meters from Kampung Pelangi. The building was previously a high court building built in 1930s during Dutch colonial era, and it was transformed into military museum in 1985. Fourth is historical monument Tugu Muda located 550 meters from Kampung Pelangi. Tugu Muda is a stone monument built in 1953 in commemoration of the struggle for Indonesian independence. Another historic site is Sam Po Kong temple located 2 kilometers from Kampung Pelangi. Sam Po Kong temple is a multiple religious denomination temple, originally established in 1400s by Chinese Muslim Explorer Zheng He. Admiral Zheng He arrived in Semarang via the Garang river now known as Semarang River during 1400s. Semarang River still exist and passes through the front of Kampung Pelangi to this day. It was believed by Kampung Pelangi residents that admiral Zheng He once stood on Brintik hill or the exact location of Kampung Pelangi today, because the high topography of Brintik hill that has a good vantage point to observe the island. There are several folk narratives about Semarang River and Bergota area, told by elderly residents of Kampung Pelangi, which are significantly important place narratives to be further explored.

\subsection{Designing the Participatory Art Model}

Art functioned in this participatory art model as communication and meaning-making process, which connect communities, place memories and simulate the imagined place expressed by the residents. According to Bourriaud (2002) in Relational Aesthetic, 'art can serve as a tool in creating and reviving relational spaces in social life'. Art functioned as symbolic exchange in society which includes the struggle to make meaning and how art relate in society by producing dialog. Art functioned as communication between artist and the community in which messages in artwork inspire spectator and strengthened communities. However the meaning making process of artwork in public space does not necessarily a sole creation by an individual artist, in the participatory art practices art is created by the communal. Quoting Bishop (2012), "participatory art aims to restore and realize a communal, collective space of shared social engagement". Participatory art produces art work that fosters " $a$ collective or co- authoring" process in meaning creation.

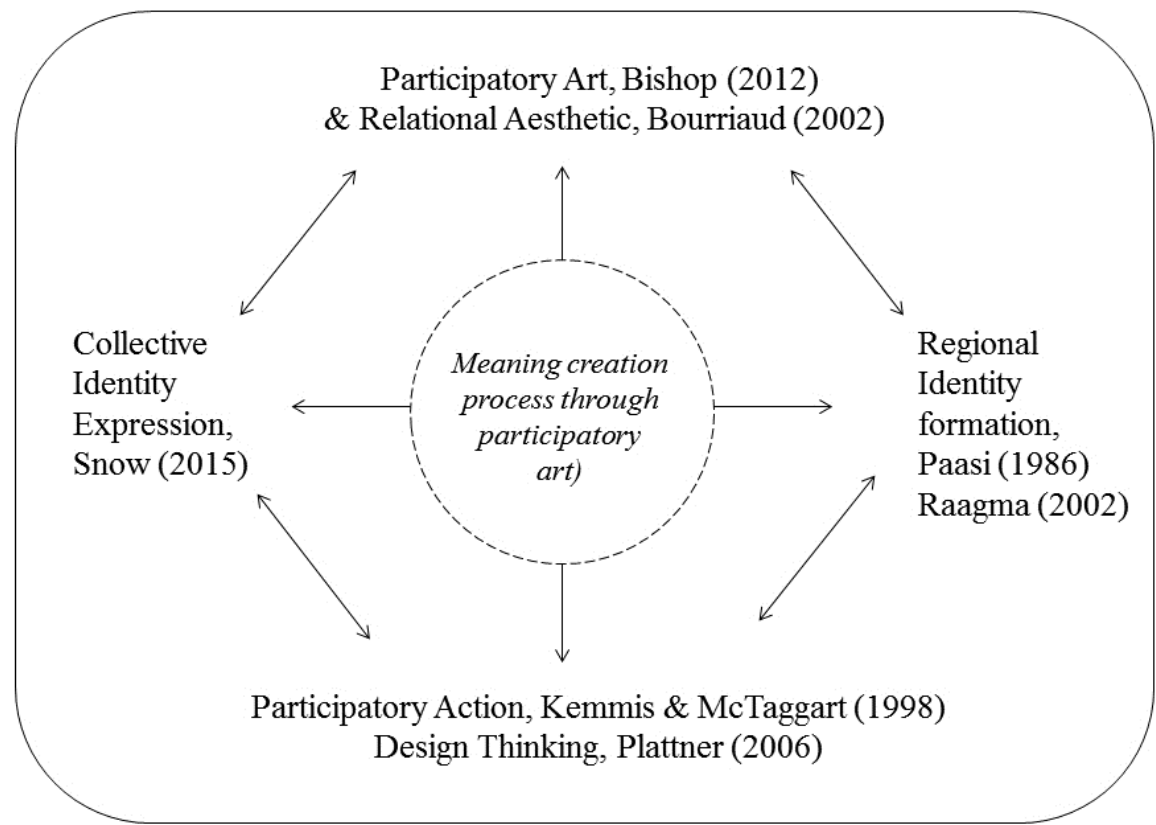

Figure 3. Theoretical paradigm leading the proposed Participatory Art Model design

To observe the meaning creation process in participatory art to shape place identity, it is necessary to outline a schema and look for a methodological basis. In participatory action research approach, actions are dissected into stages, performed in iteration and thoroughly evaluated. According to Kemmis and McTaggart (1998), action research consists of four stages in each cycle of iteration: Plan, Action, Observe and Reflect. 'Plan' is the early stage to identify problems of the research, followed by 'Act' which is the implementation of the action. 'Observe' is where researcher conducts a thorough observation of all the activities and process during the research. 'Reflect' is to examine the effect of the action, evaluate and write recommendations. 
Based on these principles, action research stages are fused by embedding art, design, visual or creative thinking process. According to Design Thinking Process developed at Stanford University Institute of Design (2016), ideation stage involves brainstorming and searching for inspirations from the surroundings. The prototype stage is when potential ideas selected, bringing multiple ideas forward, settling on the single idea that the majority of the team can agree upon. Final stage in the design process is when prototypes are tested, involving planning and executing a successful testing scenario. The participatory art approach use similar factors, which involve ideation process and searching for ideas where combination of conscious and unconscious mind takes place. In participatory art, community engagement is transmitted by visual and verbal and these approaches will underlie this study

Based on theoretical paradigms and principles mentioned earlier in the study, a proposed participatory engagement model is simplified, modified and comprised based on concept of Kemmis and McTaggart's action research iteration process (1998); Design Thinking Process at D.School Stanford (2011); Place Identity Formation concept by Raagma (2002) and Paasi (1986); Relational Aesthetics by Bourriaud (2002); Vernacular Creativity by Heath (2009); Participatory Art by Bishop (2012); and Collective Identity expression by Snow (2015). The study begins with understanding of tangible and intangible aspects of places, which include the geographical history and the contemporary conditions or problems. The action research focuses on community members. Before entering the action stage, researchers identified existing local communities and their activities or programs.

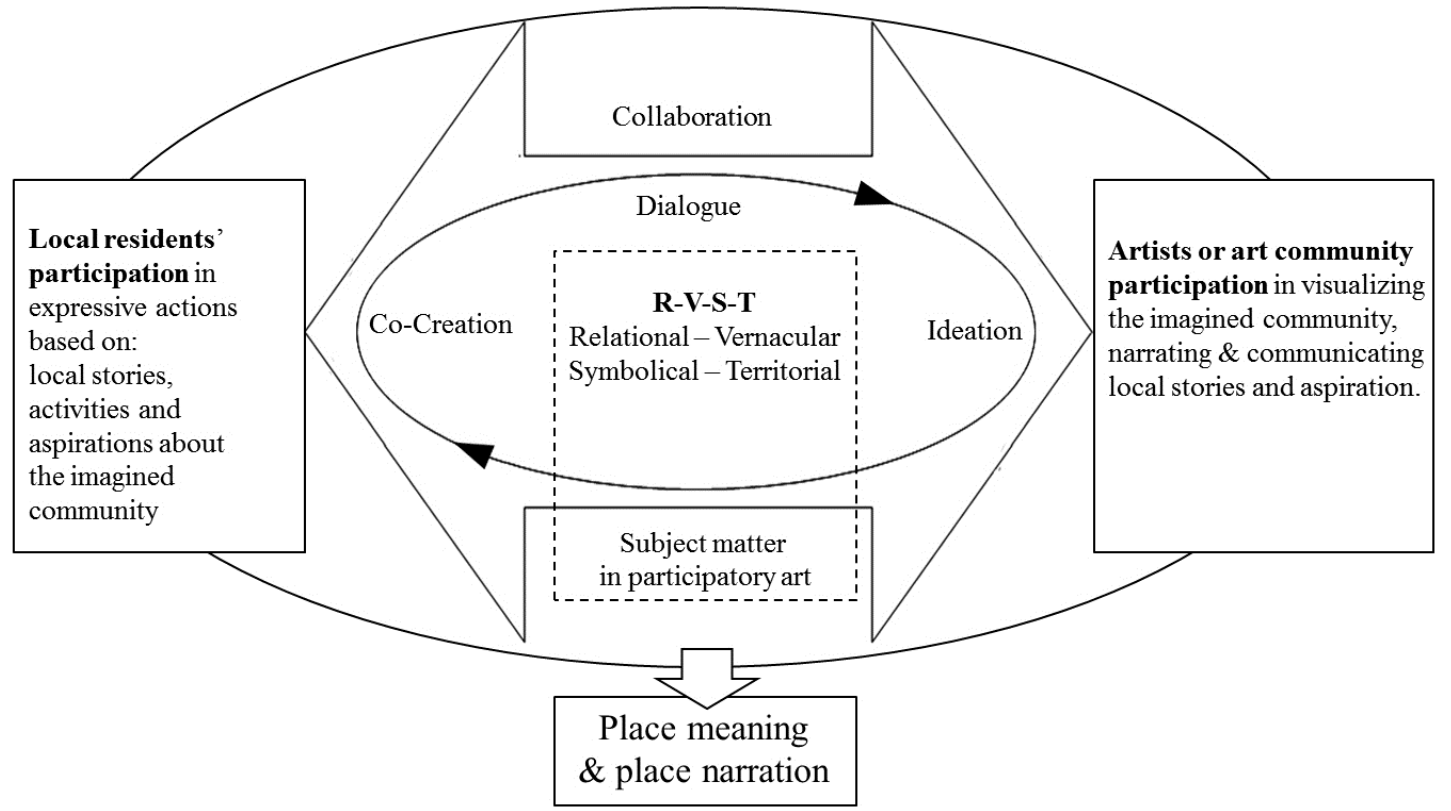

Figure 4. Meaning creation process in R-V-S-T participatory art model

The action stage start with dialogue, the process began with residents' empathy and concerns towards the place and residents' understanding about the importance to sustain the environment. To understand place identity is to examine the people's place preferences, which are influenced by everyday activities and local knowledge. The everyday activities, knowledge gathered and residents' aspiration culminate in a collective discourse and produce place narration. According to Anderson (1983) places are constructed by public discourse which is participative process in civic life, and public discourse produced the "imagined community". 


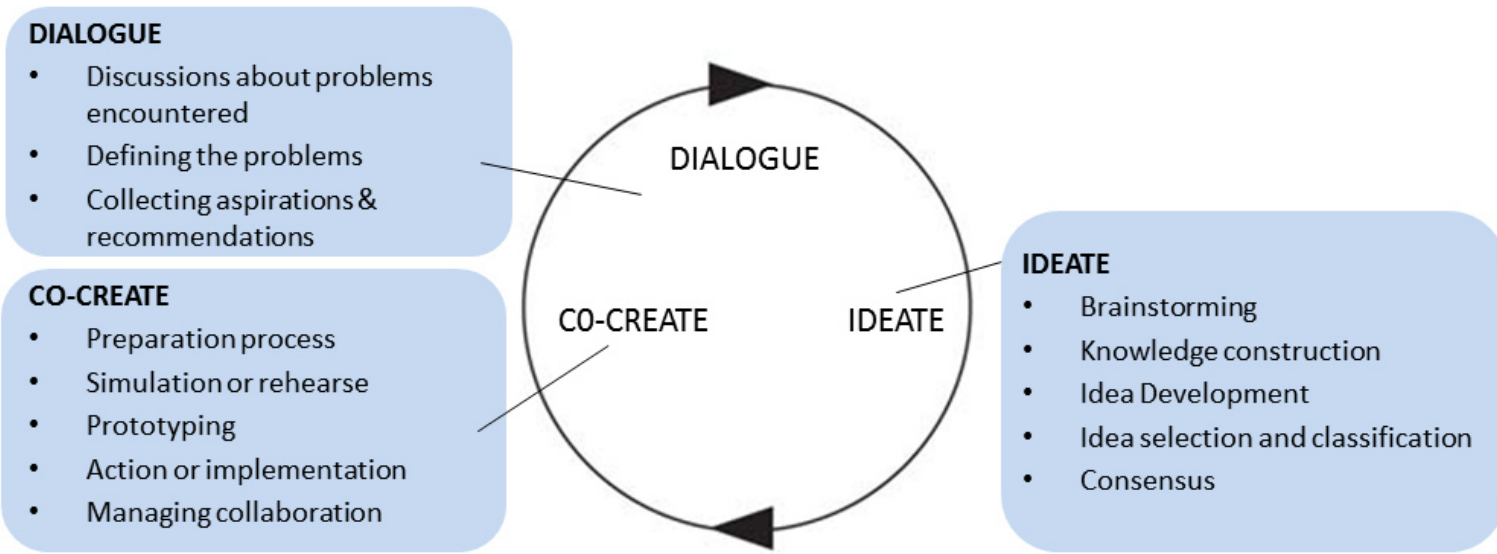

Figure 5. Engagement stage action cycle

The stage followed by 'Ideate', this is a collaborative process in finding solutions to the problem at hand. This stage involves brainstorming, exchanging ideas and reaching consensus. The 'Co-create' is the implementation of ideas by making mock-ups, conduct rehearsals, plan and finally create solutions in a collaborative process.

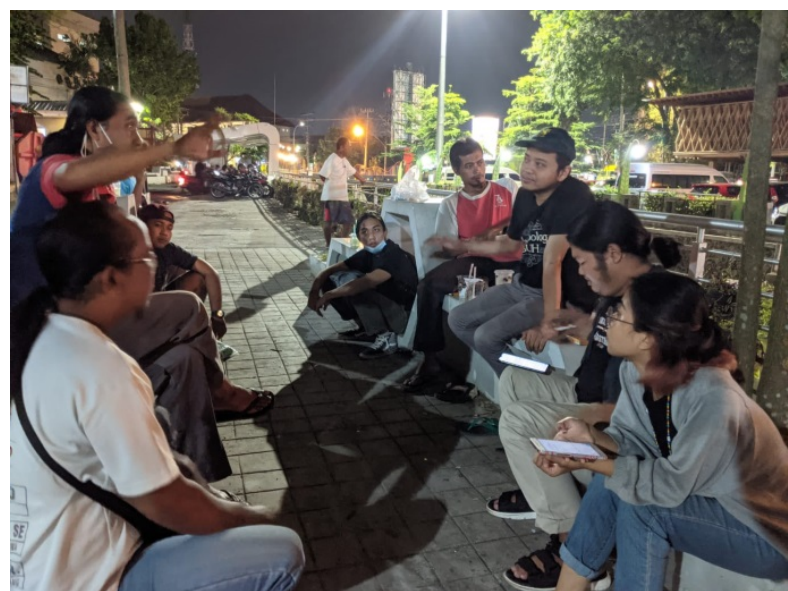

Figure 6. Dialogue between educators, community and university students with Kampung Pelangi residents

At dialog stage, facilitator gather information from residents about their past experiences, problems encountered, aspirations and recommendations. Smaller or larger group discussions can be conducted accordingly. Close communication between stakeholders and local communities (or citizens) should also be established to discuss further planning, implementation and evaluation. Ideate stage is about knowledge construction and knowledge distribution among residents or stakeholders. At this stage activities conducted to find solutions for existing problems and explore new possibilities that can be implemented in the area. Involvement and activeness of participants, especially residents in providing ideas, involving in brainstorming process or any kind of forming opinion method are the most important factors. The ideas from the participants are then categorized, the final ideas presented and selected by voting to reach a consensus. Co-create stage is when residents are involve in the process of implementing ideas together with stakeholders in a collaborative process. This stage involve planning, managing materials needed and staging an event.

\subsection{Participatory Art Project in Kampung Pelangi Semarang 2021 (Action Stage)}

The participatory art action stage is a collaborative effort between Kampung Pelangi residents, artist communities, university educators and students. The action stage started with a forum, conducted in a series of focus group discussions during dialogue stage. Residents' aspirations are communicated by the Semarang River Community (PAKAS) in the forum. The forum also participated by Kolektif Hyteria, an artist community based in Semarang, the organization main concern are on urban issues and social development through art and cultural activites. The forum initiated a participatory art project and organizing "PAKAS" event to celebrate the 474th anniversary of the City of Semarang on May 2, 2021. "PAKAS" is short form from the words "Panggilan Kali Semarang" or Semarang River Calling. The event is based on the concept of tracing Semarang history. The event started with discussion forum. 


\subsubsection{Exploring geographical history}

The discussions forum explores factual data according to the historians. Geographical history discussions connect facts with the narratives which are inherent in everyday stories among residents which have been passed down from generation to generation. The discussion led by Semarang historians, Achmad Rukardi. The discussions explored the geographical history of Kampung Pelangi area, which was once a busy port known as Bergota Port in $9^{\text {th }}$ century. Stories heard by the residents from their ancestors, mentioned that in the past large boats frequently passed through the Semarang River. The historical facts described that in the past Semarang River was a boat passage to the inner land of Semarang since $9^{\text {th }}$ century and it was utilized as water transportation to distribute timbers for building materials during Dutch colonial era during 1800s.
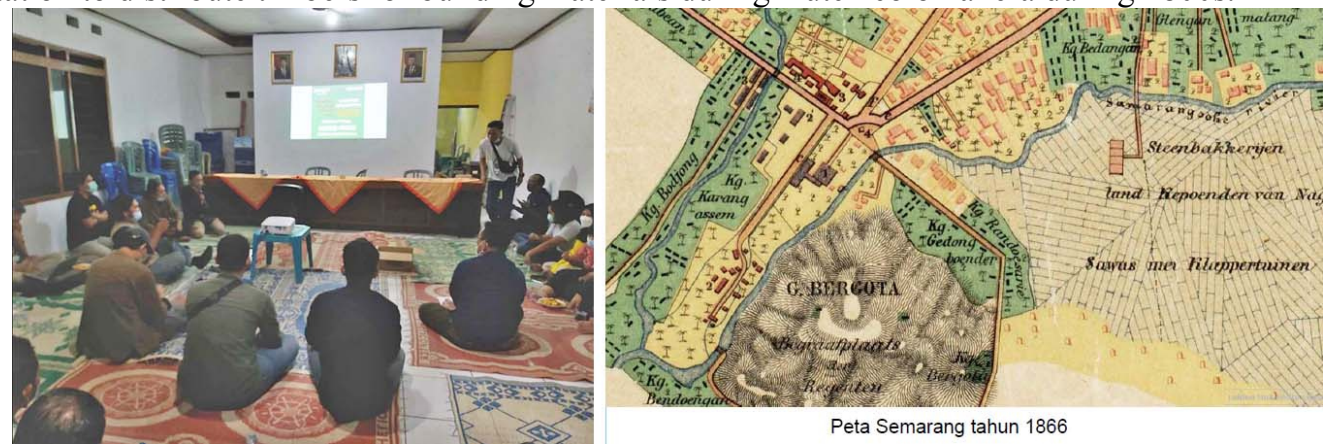

Figure 7. Left - Geographical discussions about Bergota area;

left- Colonial map showing Bergota area in 1886.

The purpose of this discussion is to explore historical knowledge and to strengthen the identity of the Wonosari Randusari area of Semarang. The historical narrative of Semarang River is an essential message, it is a calling message for the residents in Randusari and the residents of Semarang city to conserve Semarang River. For Kampung Pelangi residents, the Semarang River that flow near the village is part of residents' identity therefore the sustainability of the Semarang River is also about the continuation of their ancestors' stories.

\subsubsection{Mural project}

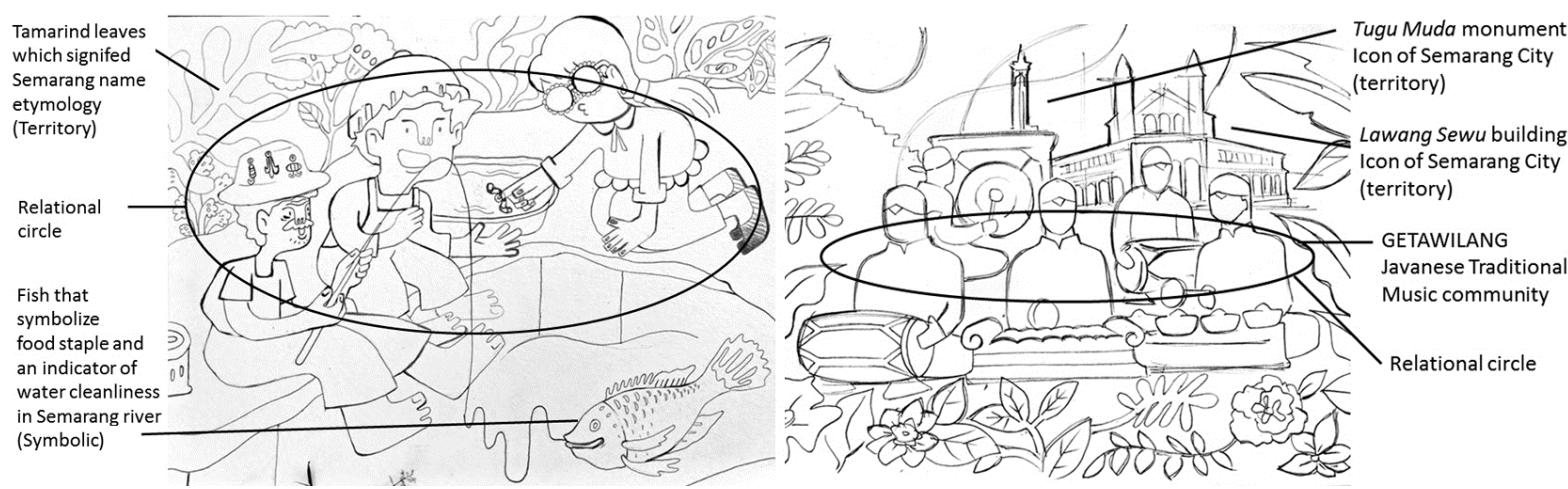

Figure 8. Sketches produced during ideate process.

Left sketch by Demak Komunal art community. Right sketch by Irwandi

The mural project participated by 6 artist communities from Semarang: Ismu, Demak Komunal, Bags and the Bake, Inonkinonk, Stokemaki and Cutnotslice art community. The mural subject matter represents Semarang River community and Semarang history. The subject matter in mural project, narrate historical past of Kampung Pelangi. The main theme of the murals is to revive and visualize historical geography of Kampung Pelangi and Semarang River which intersects with the history of Semarang City. 


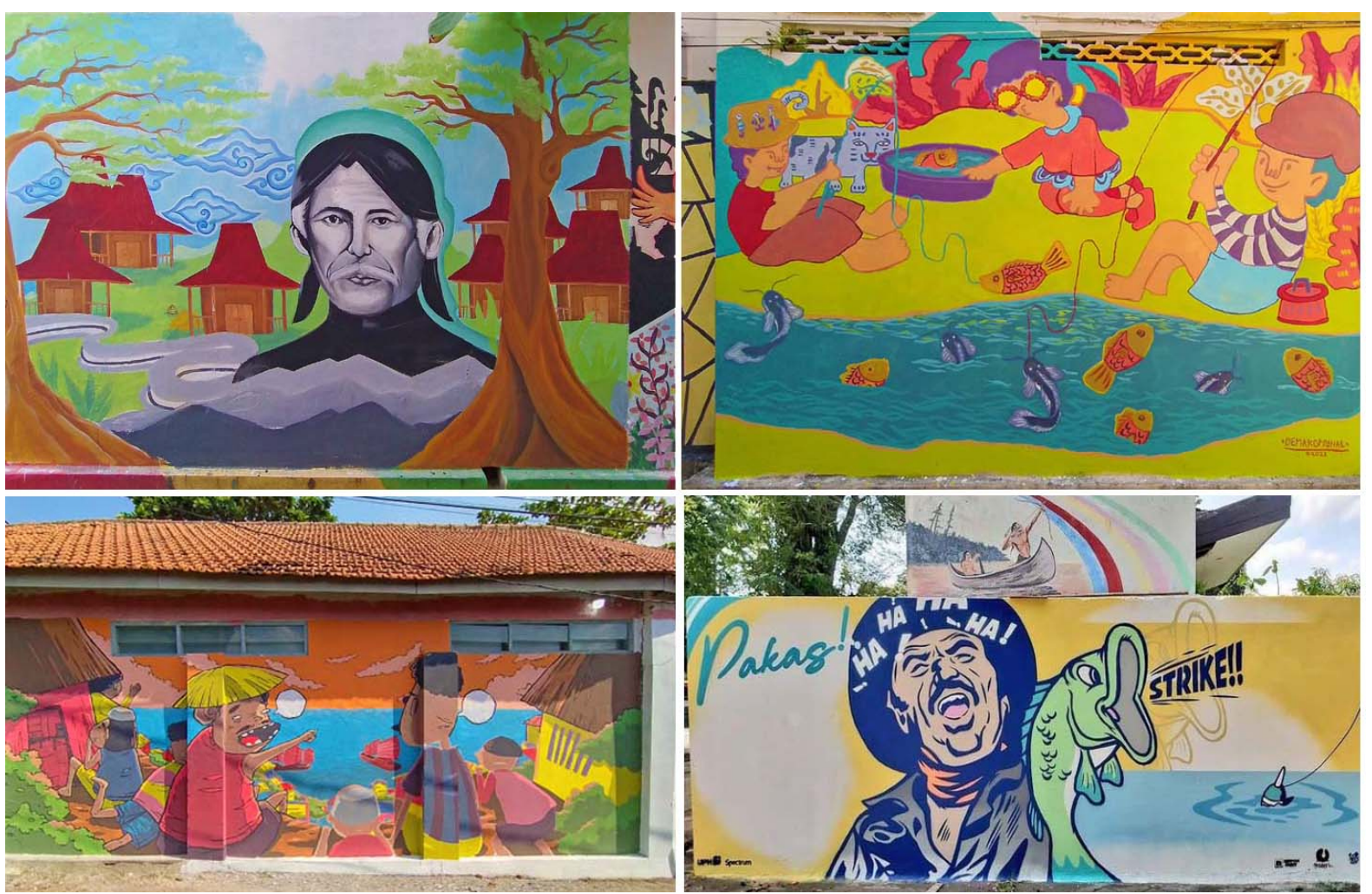

Figure 9. Murals at the 2021 Semarang River Calling event. Top left: Mural by Bags and the Bake art community. Top right: Mural by Demak Komunal art community. Bottom left: Demak Komunal art community.

Bottom right: Mural by Cutnotslice art community.

The mural at the top left of figure 9, was created by Bags and the Bake art community. The mural depicted the figure of Ki Ageng Pandanaran, the first regent and founder of Semarang city. The background illustrate tamarind trees, this mural narrates when Ki Ageng Pandanaran arrived at Tirang area and he found the area filled with tamarind tree that was planted spaced apart, and named the area Semarang or 'spaced apart tamarind trees' in Javanese word.

The mural at the top right and bottom right of figure 9, were created by Demak Komunal and Cutnotslice art community. The mural depicted the fun atmosphere when fishing together at Semarang River. The subject area grouped together in a 'relational circle' which represent togetherness. The togetherness and the enjoyment of fishing together utter message to the people to conserve Semarang River. The mural by Demak Komunal art community at the bottom left of figure 9, depicted the crowded Bergota harbor sometime in the past, the foreground of the mural illustrate local people overlook the sea from the Brintik hill and witnessed sailing ships docked at Bergota. In this mural the houses are painted with colorful tone which represents the current condition of Kampung Pelangi. The mural suggest the juxtaposition between the past and present of Semarang City from Kampung Pelangi's viewpoint.

The participatory art performed at Semarang River Calling event, echoes the participatory art performed in Citarum Riverbank in Bandung. According to Lakoro (2021), participatory art practiced at Citarum Riverbank aimed to re-nurture the river culture and instill sense of crisis among the residents and a call to involve in a cultural movement. Hidayatullah (2020), conveyed that mural is a medium that can develop environmental literacy. The mural creation in Kampung Pelangi is a call to younger generation to express regional identity, thus instilling a sense of belonging and uniting values in a community. The Kampung Pelangi narration cultivated based upon relational, vernacular, symbolical and territorial expression can be a strong bond for residents. The participatory art helps to visualize the 'imagined society' that creates sense of belonging and sense of pride among residents. These senses of belongings may motivate actions to conserve the environment and nurture cultural values which may lead to place sustainability.

\section{Conclusion}

Participatory art in the rainbow village is a process of discovering shared identity, exploring historical events and expressing their local identities by creating colorful murals, organizing festivals, rejuvenating historical and cultural heritage. The relational, vernacular, symbolical and territorial expressions (RVST) not only functioned as art theme visualized in the art work, but also in various actions which may be evolve and transforming the place. Contemporary art development in the context of appreciating and experiencing art, not only oriented on 
aesthetic dimension but have expanded towards collective dimensions (Kusmara, A.R, 2011). Participatory art performed in public spaces does not only reflect the image of the artist, or the image of a gallery or currator, but also the image of places and communities. The participatory art approach as stated in the previous section is expected to be able to determine citizen participation in collaborative idea formation. This model can also show artists' and facilitators' roles in cultivating community expressions that may become a catalyst and sparks creative movement to local communities.

\section{References}

Anderson, B. (1983). Imagined communities. London: Verso.

Barnett, A.W. (1984). Community Murals: The People's Art. Cranbury, NJ: Associated University Press, Inc.

Bishop, C. (2012). Artificial hells: participatory art and the politics of spectatorship. London: Verso.

Bourriaud, N. (2002). Relational Aesthetics. Translated by Simon Pleasance, Fronza Woods and Mathieu Copeland. Paris: Les presses du reel.

Burns, A. (2010). Doing action research in English language teaching: A guide for practitioners. New York: Routledge.

Fine, G. A. (2014). Everyday Genius: Self-Taught Art and the Culture of Authenticity.

Gray, A., \& McGuigan, J. (1993). Studying Culture an Introductory Reader. London, Arnold, 1993.

Heath,K. (2016). Vernacular architecture and regional design. Taylor \& Francis.

Kindon, S., Pain, R., \& Kesby, M. (2007). Participatory Action Research Approaches and Methods: Connecting people, participation and place. London: Routledge.

Hidayatullah, T., Sabana, S., Sanjaya, T., Mutiaz, I.R. (2021). Environmental Literacy Education through Mural Artwork at Madrasah Diniyah Awaliyyah Al Qamariyyah in Ciroyom Bandung, Arts and Design Studies , 91, 10-17.

Lakoro, R., Sachari, A., Budiwaspada, A. E., Sabana, S. (2020). Participatory Art as Disaster Education in Bojongsoang District of Bandung Regency, Arts and Design Studies , 87, 40-44.

Kusmara, A.R. (2011). "Medium Seni dalam Medan Sosial Seni Rupa Kontemporer Indonesia". Disertasi Program Doktor Ilmu Seni Rupa dan Desain, Institut Teknologi Bandung.

Lefebvre, H. (1991). Production of space. Oxford: Blackwell.

Massey, D. (1993). A Global Sense of Place: Studying Culture an Introductory Reader. London, Arnold.

Paasi, A. (1986). The Institutionalization of Regions: a Theoretical Framework for the Understanding of the Emergence of Regions and the Constitutions of Regional Identity. Fennia 164, pp. 105-146.

Paasi, A (2003). Region and place: regional identity in question. Progress in Human Geography, 28, 475-485.

Plattner, H., Meinel, C. and Leifer, L. (2011). Design Thinking. Berlin: Springer.

Raagmaa, G. (2002) Regional Identity and Social Capital In Regional Economic Development and Planning.

Tunnacliffe, C.M. (2016). The Power of Urban Street in Re-Naturing Urban Imaginations and Experiences, London, The Bartllet, London, University College London.

Stanford University Institute of Design. (2016). D.school design thinking process. Retrieved from http://dschool.stanford.edu/ 